\title{
ANALYSIS OF THE IMPACT OF LIQUIDITY ON THE PROFITABILITY IN THE MEDIUM AND LARGE MEAT PROCESSING ENTERPRISES IN THE REPUBLIC OF SERBIA
}

\author{
Miroslav Čavlin ${ }^{1}$, Jelena Vapa Tankosić2 ${ }^{2}$ Vesna Miletić ${ }^{3}$, Miloš Ivaniš \\ *Corresponding author E-mail: cmiros@gmail.com
}

\begin{tabular}{l} 
A R T I C L E I N F O \\
Original Article \\
Received: 21 July 2021 \\
Accepted: 10 August 2021 \\
doi:10.5937/ekoPolj2103789C \\
UDC 330.13:334.012.61- \\
022.55/.56]:637.51(497.11) \\
\hline
\end{tabular}

Keywords:

liquidity, profitability, return on assets, processing and preserving of meat and meat products, Serbia.

JEL: M41, G32

\begin{abstract}
A B S T R A C T
Liquidity and profitability are closely related economic categories. The issue of constant balancing between liquidity and profitability, in theory known as "liquidityprofitability trade off', has been the subject of significant interest of the scientific community. There is no consensus on the direction of the impact of liquidity on profitability, but the existence of this impact in practice is confirmed. The aim of this paper is to investigate the impact of liquidity on profitability, based on selected traditional financial indicators, for medium and large enterprises in the group of processing and preserving of meat and meat products of the Republic of Serbia, in the period 2016 to 2019. The findings of a multiple linear regression analysis, show that the ratio of long-term sources and fixed assets in the group of processing and preserving of meat and meat products makes a statistically significant contribution predicting the return on assets.
\end{abstract}

(C) 2021 EA. All rights reserved.

\section{Introduction}

Profitability and liquidity stand out as basic measures of sustainability and operational flexibility and represent the focus of the management orientation of modern companies. Liquidity is a traditional, primary measure of the survival or disappearance of a company. In our approach, solvency is not equated with liquidity, but is understood as the ability

1 Miroslav Čavlin, Full professor, Faculty of Economics and Engineering Management in Novi Sad, University Business Academy, Cvećarska 2, 21000 Novi Sad, Republic of Serbia, E-mail: cmiros@gmail.com, ORCID ID (https://orcid.org/0000-0001-7465-7441)

2 Jelena Vapa Tankosić, Full professor, Faculty of Economics and Engineering Management in Novi Sad, University Business Academy, Cvećarska 2, 21000 Novi Sad, Republic of Serbia, E-mail: jvapa@fimek.edu.rs, ORCID ID (https://orcid.org/0000-0001-8062-1154)

3 Vesna Miletić, Ph. D., Associate Professor, Faculty of Management, Sremski Karlovci, University "Union -Nikola Tesla", Belgrade, Serbia, E-mail: vmiletic68@gmail.com, vesna.miletic@famns.edu.rs, ORCID ID (https://orcid.org/0000-0003-1287-5800)

4 Miloš Ivaniš, PhD student, Faculty of Economics and Engineering Management in Novi Sad, Cvećarska 2, 21000 Novi Sad, Republic of Serbia, E-mail: prof.drmivanis@gmail.com 
of a company to properly settle all its obligations and maintain stable operations in the foreseeable future (Čavlin, 2020; Radić et al., 2020). Liquidity and profitability management requires a platform (Čavlin, 2015; Milojević et al., 2020; Jokić, 2020), which will enable the smooth flow of business operations of the company, both material and financial in a certain harmony without delay, with maximum profitability, and for the lasting benefit of the company. Based on previous theoretical research, it can be concluded that there is no consensus on the direction of the impact of liquidity on profitability, but the existence of this impact in practice is mostly confirmed.

In accordance with the above, the paper has the following goals:

- the ratio analysis of liquidity and profitability of medium and large enterprises in the processing and preserving of meat and meat products of the Republic of Serbia, and

- the analysis of interdependence and the impact of liquidity on the profitability of assets based on traditional indicators.

Our initial hypothesis is that there is an impact of liquidity on profitability, but there is no consensus on the direction of that impact, and the causes of differences are determined by a number of factors, so the focus of research is on medium and large companies from the group- 10.1 in the processing and preserving of meat and meat products of the Republic of Serbia, in order to create a practical basis for a rational analysis of liquidity and profitability based on traditional financial indicators .In order to achieve the goal of the paper, along with the analysis of relevant literature, in theoretical aspects, typical parameters for liquidity and profitability are analyzed, in meat processing activity in the Republic of Serbia, using data from official financial reports of the companies in the Republic of Serbia for the period from 2016 to 2019 and performing an analysis of the impact of traditional liquidity indicators on the profitability. The paper is structured as follows: an overview of the literature on liquidity and profitability is presented below. The research method is then described, followed by results and discussion. The last section contains concluding remarks.

\section{Literature review}

The subject of significant interest, in theory and practice, is the issue of optimal balancing between liquidity and profitability so called ,liquidity- profitability trade off" (Smith, 1980). A sustainable compromise between liquidity and profitability, without neglecting one to the detriment of other management values, is crucial for rational business management and the vitality of the company. The choice of a rational management response in practice is not simple, on the contrary, and the results of scientific research that has dealt with the analysis of different modalities of the relationship between liquidity and profitability are not unambiguous. So, the problem of so-called "Liquidity -profitability trade off" is complex, and below we will highlight the main results of certain research in terms of the existence and quality of the relationship between liquidity and profitability. From one aspect, the existence of a negative relationship between liquidity and profitability is indicated by research 
findings of: Deloof (2003), Afza et al. (2007), Mohamed and Saad (2007), Samilogu et al. (2008), Bagchi et al. (2012), Saluja et al. (2012), Priya et al. (2013), Ehiedu (2014) and Raykov (2017). Eljelly (2004) confirms the negative relationship between profitability and liquidity on a sample of companies in Saudi Arabia, by applying correlation and regression analysis, but emphasizes the need to respect the differences between different industries. By analyzing 88 companies listed on the New York Stock Exchange, Gill et al. (2010) confirms the negative relationship between profitability (measured by gross operating profit) and the average period of receivables, but also the positive relationship between the duration of the cash cycle and profitability.

From another aspect, the existence of a positive relationship between liquidity and profitability is indicated by research findings of: García-Teruel and Solano (2007), Uyar (2009), Lamberg and Vålming (2009), Maçãs Nunes et al. (2010), Saleem and Rehman (2011), Makori and Jagongo (2013) and Mohamed and Hazem (2015).

The issue of "liquidity -profitability trade off" in developing countries has also been explored by Ehi-Oshio et al. (2013) on a sample of 40 Nigerian companies in the period 2006-2010, and based on regression analysis, a positive relationship between the size of the company and its profitability as well as between financial leverage and profitability, while a negative relationship was observed between capital structure and liquidity ( measure: the sum of cash and cash equivalents) and the profitability of the enterprise. Mamić Sačer et al. (2013), analyze the impact of liquidity on the profitability of medium and large enterprises in the information and communication industry on a sample of 44 enterprises in the period 2007-2009 in the Republic of Croatia, and on the basis of correlation and regression analysis of selected liquidity and profitability indicators, they have determined the existence of a positive correlation, although of low intensity, between the current liquidity ratio and the gross return on assets indicator, from which it follows that the increase in the value of the current liquidity ratio affects the increase in the value of the gross return on assets for the analyzed companies.

The issue of "liquidity profitability trade off" in Serbia has not been sufficiently researched, and in this context research of Lukić (2012), Jovanović et al. (2017), Čavlin and Tepavac (2020) Stevanović et al. (2021). Denčić-Mihajlov (2015) suggests that larger and more liquid companies also show higher profitability, while the findings of Stevanović et al. (2019) show a significant positive relationship between quick ratio of liquidity, operating cash flow margin and cash flow investment margin on profitability measured by return on assets, and the statistically significant ratio of current liquidity indicators, liquidity indicators of operational and financial net cash flow on profitability.

When it comes to the choice for the selection of the relevant indicator of the given categories, it should be noted that it Levin and Travis (1987) pointed out to analyse ROCA instead of ROA and ROE as being deformed by shareholders' decisions to lease company's assets, while an indicator of liquidity to use working capital sufficiency, cash conversion cycle, and current or acid-test liquidity ratio. The quick ratio behaviour and impact on profitability was investigated by Ahmad (2016), Irawan and Faturohman (2015), Khidmat and Rehman (2014) and Kung'u (2017). 


\section{Materials and methods}

In order to achieve the goal of the paper, typical parameters for liquidity and profitability analysis shall be analyzed, specifically the position of liquidity and profitability of meat processing activity in the Republic of Serbia, using data from official financial reports of the companies in the Republic of Serbia for the period from 2016 to 2019. The authors shall perform an analysis of the quality of the impact of traditional liquidity indicators on the profitability by using descriptive analysis and multiple linear regression analysis of the influence of two or more explanatory variables on the dependent variable will be used.

By applying this type of regression, the authors wanted to determine what percentage of the variability of the dependent variable was explained by a particular set of independent variables and the relative contribution of each independent variable included in the regression analysis (Rosner, 2011; Radović Marković, Hanić, 2018).

$$
\ln \left(\frac{p}{1-p}\right)=\beta_{0}+\beta_{1} X_{1}+\beta_{2} X_{2}+\cdots \beta_{n} X_{n}
$$

The assumptions of employed multiple linear regression model are:

1. linearity as the relationship between $\mathrm{X}$ and the mean of $\mathrm{Y}$ is linear;

2. $\mathrm{Y}$ is a random variable, because it represents a function of e and $\mathrm{X} 1, \mathrm{X} 2 \ldots \mathrm{Xk}$, are not random variables;

3. the expected value of the random error is 0 ;

4. there is no autocorrelation (random errors are mutually independent);

5. homoskedasticity (equality of variances of random errors) - the variance of residual is the same for any value of $\mathrm{X}$;

6. normal distribution of random errors;

7. explanatory variables are not mutually linearly dependent, i.e. there is no problem of multicollinearity.

The sample size is satiosfgactory as it require as a minimum at least 20 cases per independent variable in the analysis.

\section{Results and discussion}

The sample includes medium and large enterprises from the Group- 101 Processing and preserving of meat and meat products, Division -10 Manufacture of food products and Section - C Manufacturing. According to the published data, medium and large companies that submitted annual financial reports for 2019 generated a total of $96,503,502.00$ dinars of operating income, which represents $71.04 \%$ of the total turnover in the Group- 101 Processing and preserving of meat and meat products, i.e. which achieved a total of RSD 2,443,100.00 net profit, which represents $74.48 \%$ of the net profit of all active companies in the Group- 101 Processing and preserving 
of meat and meat products (hereinafter: meat processing activity). The situation is similar throughout the study period. Given this, the results obtained can be considered representative for the adoption of conclusions. The ratio analysis of liquidity and profitability of the observed companies was performed by analyzing:

- the average values of typical liquidity and profitability indicators for enterprises from the sample of meat processing activity, and

- the range of values of individual liquidity and profitability indicators for enterprises from the sample of meat processing activity and their grouping in accordance with the determined limit values.

By analyzing the obtained results, it is possible to point out the following liquidity and solvency parameters in the Table 1, as follows:

- all average values of liquidity indicators for companies show worse values than the desired theoretical norms, but also slightly better outcomes than the average value than those for the entire meat processing industry.

- the representation of companies that have the value of liquidity ratios below the values of the desired theoretical norms is significant, especially in the ratio of cash quick liquidity.

- considering all liquidity indicators, a high representation of companies with lower value of the expressed indicators than the desired theoretical norms is noticeable, which implies an unfavorable assessment of liquidity and unfavorable conditions for financially stable business operations of the company.

Table 1. Average and grouped liquidity ratios 2016-2019

\begin{tabular}{|c|c|c|c|c|c|c|c|c|c|c|c|c|}
\hline Period & & 2019 & & & 2018 & & & 2017 & & & 2016 & \\
\hline $\begin{array}{l}\text { Liquidity } \\
\text { coefficient } \\
\text { ranges }\end{array}$ & 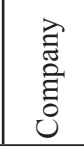 & $\%$ & $\%$ & 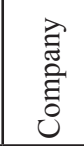 & $\%$ & $\%$ & 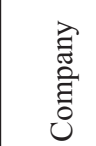 & $\%$ & $\%$ & 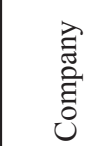 & $\%$ & $\%$ \\
\hline \multicolumn{13}{|c|}{ Coefficient of current (cash) liquidity } \\
\hline $0,00-0,09$ & 24 & 88,89 & & 20 & 83,33 & & 12 & 63,16 & & 13 & 86,67 & \\
\hline $0,10-0,29$ & 2 & 7,41 & 96,3 & 2 & 8,33 & 95,8 & 4 & 21,05 & 100 & 1 & 6,67 & 100 \\
\hline $0,30-0,99$ & 0 & 0,00 & & 1 & 4,17 & & 3 & 15,79 & & 1 & 6,67 & \\
\hline$\geq 1,00$ & 1 & 3,70 & 3,7 & 1 & 4,17 & 4,2 & 0 & 0,00 & & 0 & 0,00 & 0,00 \\
\hline $\begin{array}{l}\text { Total number } \\
\text { of companies }\end{array}$ & 27 & 100 & 100 & 24 & 100 & 100 & 19 & 100 & 100 & 15 & 100 & 100 \\
\hline $\begin{array}{l}\text { Average } \\
\text { sample } \\
\text { realization } \\
\end{array}$ & 0,16 & & & 0,13 & & & 0,09 & & & 0,08 & & \\
\hline $\begin{array}{l}\text { Average } \\
\text { performance }\end{array}$ & 0,15 & & & 0,07 & & & 0,05 & & & 0,06 & & \\
\hline \multicolumn{13}{|c|}{ Coefficient of current (general) liquidity } \\
\hline $0,00-0,99$ & 12 & 44,44 & & 5 & 20,83 & & 5 & 26,32 & & 4 & 26,67 & \\
\hline
\end{tabular}




\begin{tabular}{|c|c|c|c|c|c|c|c|c|c|c|c|c|}
\hline Period & & 2019 & & & 2018 & & & 2017 & & & 2016 & \\
\hline $\begin{array}{l}\text { Liquidity } \\
\text { coefficient } \\
\text { ranges }\end{array}$ & 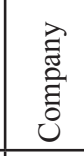 & $\%$ & $\%$ & 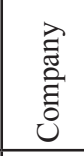 & $\%$ & $\%$ & 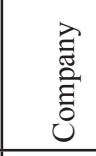 & $\%$ & $\%$ & $\begin{array}{l}\text { त्ञ } \\
\text { छे } \\
\text { 己 }\end{array}$ & $\%$ & $\%$ \\
\hline $1,00-1,39$ & 7 & 25,93 & 88,9 & 10 & 41,67 & 75,0 & 7 & 36,84 & 84,2 & 5 & 33,33 & 86,7 \\
\hline $1,40-1,99$ & 5 & 18,52 & & 3 & 12,50 & & 4 & 21,05 & & 4 & 26,67 & \\
\hline$\geq 2,00$ & 3 & 11,11 & 11,1 & 6 & 25,00 & 25,0 & 3 & 15,79 & 15,8 & 2 & 13,33 & 13,3 \\
\hline $\begin{array}{l}\text { Total number } \\
\text { of companies }\end{array}$ & 27 & 100 & 100 & 24 & 100 & 100 & 19 & 100 & 100 & 15 & 100 & 100 \\
\hline $\begin{array}{l}\text { Average } \\
\text { sample } \\
\text { realization } \\
\end{array}$ & 1,38 & & & 1,6 & & & 1,48 & & & 1,35 & & \\
\hline $\begin{array}{l}\text { Average } \\
\text { performance }\end{array}$ & 1,08 & & & 0,93 & & & 0,89 & & & 0,94 & & \\
\hline \multicolumn{13}{|c|}{ Coefficient of solvency (financial stability) } \\
\hline $0,00-0,49$ & 12 & 44,44 & & 12 & 50,00 & & 9 & 47,37 & & 6 & 40,00 & \\
\hline $0,50-0,79$ & 3 & 11,11 & 63,0 & 1 & 4,17 & 62,5 & 2 & 10,53 & 63,2 & 1 & 6,67 & 66,7 \\
\hline $0,80-0,99$ & 2 & 7,41 & & 2 & 8,33 & & 1 & 5,26 & & 3 & 20,00 & \\
\hline $1,00-1,49$ & 8 & 29,63 & & 8 & 33,33 & & 5 & 26,32 & & 3 & 20,00 & \\
\hline $1,50-1,99$ & 1 & 3,70 & 37,0 & 1 & 4,17 & 37,5 & 2 & 10,53 & 36,8 & 1 & 6,67 & 33,3 \\
\hline$\geq 2,00$ & 1 & 3,70 & & 0 & 0,00 & & 0 & 0,00 & & 1 & 6,67 & \\
\hline $\begin{array}{l}\text { Total number } \\
\text { of companies }\end{array}$ & 27 & 100 & 100 & 24 & 100 & 100 & 19 & 100 & 100 & 15 & 100 & 100 \\
\hline $\begin{array}{l}\text { Average } \\
\text { sample } \\
\text { realization }\end{array}$ & 0,63 & & & 0,65 & & & 0,58 & & & 0,65 & & \\
\hline $\begin{array}{l}\text { Average } \\
\text { performance }\end{array}$ & 0,62 & & & 0,59 & & & 0,57 & & & 0,57 & & \\
\hline
\end{tabular}

Source: Authors' calculations

By analyzing the results, it is possible to point out the following parameters of profitability in the Table 2:

- most of the average values of profitability indicators for the companies from the sample, show worse values than the desired norms, but also slightly better results than the average values than those expressed for the entire meat processing activity.

- the representation of companies that have the value of profitability indicators below the values of the desired theoretical norms is dominant, except for the value of indicators of return on capital, where $44.4 \%$ of companies are ranked.

- the analysis of profitability indicators shows a significant representation of companies with worse values of the expressed indicators than the desired norms, which implies an unfavorable assessment of the company's profitability in the analyzed sample, and in the observed period. 
Table 2. Average and grouped profitability indicators 2016-2019

\begin{tabular}{|c|c|c|c|c|c|c|c|c|c|c|c|c|}
\hline $\begin{array}{l}\text { Period of } \\
\text { time }\end{array}$ & & 2019 & & & 2018 & & & 2017 & & & 2016 & \\
\hline $\begin{array}{l}\text { Range of } \\
\text { indicators }\end{array}$ & 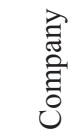 & $\%$ & $\%$ & 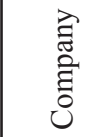 & $\%$ & $\%$ & 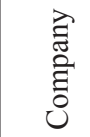 & $\%$ & $\%$ & $\begin{array}{l}\grave{\Xi} \\
\text { ڤ్ } \\
\text { ठ }\end{array}$ & $\%$ & $\%$ \\
\hline \multicolumn{13}{|c|}{ Net profit margin } \\
\hline 0 & 5 & 18,5 & & 10 & 41,7 & & 5 & 26,3 & & 5 & 33,3 & \\
\hline $0,01-0,049$ & 18 & 66,7 & 85,2 & 10 & 41,7 & 83,3 & 11 & 57,9 & 84,2 & 6 & 40,0 & 73,3 \\
\hline $0,05-0,099$ & 4 & 14,8 & 14,8 & 3 & 12,5 & & 3 & 15,8 & 15,8 & 4 & 26,7 & \\
\hline $0,10-0,19$ & & & & 1 & 4,2 & 14,8 & & & & 0 & 0,0 & 26,7 \\
\hline $\begin{array}{l}\text { Total number } \\
\text { of companies }\end{array}$ & 27 & 100,0 & 100 & 24 & 100 & 100 & 19 & 100,0 & & 15 & 100 & 100 \\
\hline $\begin{array}{l}\text { Average } \\
\text { sample } \\
\text { realization }\end{array}$ & 0,02 & & & 0,2 & & & 0,2 & & & 0,03 & & \\
\hline \begin{tabular}{l|} 
Average \\
performance
\end{tabular} & 0,02 & & & 0,04 & & & 0,03 & & & 0,03 & & \\
\hline \multicolumn{13}{|c|}{ Gross profit margin } \\
\hline \begin{tabular}{l|l}
0 \\
\end{tabular} & 3 & 11,1 & & 4 & 16,7 & & 3 & 15,8 & & 2 & 13,3 & \\
\hline $0,01-0,049$ & 18 & 66,7 & 77,8 & 16 & 66,7 & 83,3 & 13 & 68,4 & 84,2 & 8 & 53,3 & 66,7 \\
\hline $0,05-0,099$ & 6 & 22,2 & 22,2 & 3 & 12,5 & & 2 & 10,5 & & 4 & 26,7 & \\
\hline $0,10-0,19$ & & & & 1 & 4,2 & 16,7 & 1 & 5,3 & 15,8 & 1 & 6,7 & 33,3 \\
\hline $\begin{array}{l}\text { Total number } \\
\text { of companies }\end{array}$ & 27 & 100,0 & 100 & 24 & 100 & 100 & 19 & 100 & 100 & 15 & 100 & 100 \\
\hline $\begin{array}{l}\text { Average } \\
\text { sample } \\
\text { realization } \\
\end{array}$ & 0,81 & & & 0,8 & & & 0,82 & & & 0,78 & & \\
\hline \begin{tabular}{l|} 
Average \\
performance
\end{tabular} & 0,79 & & & 0,8 & & & 0,82 & & & 0,79 & & \\
\hline \multicolumn{13}{|c|}{ Return on assets (ROA) } \\
\hline \begin{tabular}{l|l}
0 \\
\end{tabular} & 2 & 7,4 & & 6 & 25,0 & & 4 & 21,1 & & 5 & 33,3 & \\
\hline $0,01-0,049$ & 19 & 70,4 & 77,8 & 8 & 33,3 & 58,3 & 8 & 42,1 & 63,2 & 4 & 26,7 & 60,0 \\
\hline $0,05-0,099$ & 5 & 18,5 & 18,5 & 7 & 29,2 & & 5 & 26,3 & & 3 & 20,0 & \\
\hline $0,10-0,19$ & 0 & & & 3 & 12,5 & 41,7 & 2 & 10,5 & 36,8 & 1 & 6,7 & \\
\hline 0,2 & 0 & & & 0 & 0 & & 0 & 0 & & 2 & 13,3 & 40,0 \\
\hline $\begin{array}{l}\text { Total number } \\
\text { of companies }\end{array}$ & 27 & 100,0 & 100 & 24 & 100 & 100 & 19 & 100 & 100 & 15 & 100 & 100 \\
\hline $\begin{array}{l}\text { Average } \\
\text { sample } \\
\text { realization } \\
\end{array}$ & 0,06 & & & 0,04 & & & 0,04 & & & 0,06 & & \\
\hline $\begin{array}{l}\text { Average } \\
\text { performance }\end{array}$ & 0,03 & & & 0,05 & & & 0,03 & & & 0,04 & & \\
\hline \multicolumn{13}{|c|}{ Return on equity (ROE) } \\
\hline$-0,01$ & & & & & & & & & & 0 & & \\
\hline 0 & 2 & 7,4 & & 6 & 25,0 & & 3 & 15,8 & & 4 & 26,7 & \\
\hline
\end{tabular}




\begin{tabular}{|c|c|c|c|c|c|c|c|c|c|c|c|c|}
\hline $\begin{array}{l}\text { Period of } \\
\text { time }\end{array}$ & & 2019 & & & 2018 & & & 2017 & & & 2016 & \\
\hline $\begin{array}{l}\text { Range of } \\
\text { indicators }\end{array}$ & 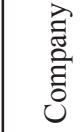 & $\%$ & $\%$ & 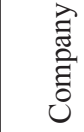 & $\%$ & $\%$ & 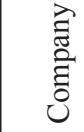 & $\%$ & $\%$ & $\begin{array}{l}\grave{\Xi} \\
\text { ڤ్ } \\
\text { ठ }\end{array}$ & $\%$ & $\%$ \\
\hline $0,01-0,049$ & 10 & 37,0 & 44,4 & 7 & 29,2 & 54,2 & 4 & 21,1 & 36,8 & 3 & 20,0 & 46,7 \\
\hline $0,05-0,099$ & 8 & 29,6 & & 4 & 16,7 & & 7 & 36,8 & & 3 & 20,0 & \\
\hline $0,10-0,19$ & 4 & 14,8 & & 6 & 25,0 & & 3 & 15,8 & & 2 & 13,3 & \\
\hline $0,2-0,39$ & 1 & 3,7 & & 1 & 4,2 & 45,8 & 1 & 5,3 & & 2 & 13,3 & \\
\hline $0,40-0,59$ & 1 & 3,7 & & 0 & 0 & & 0 & 0,0 & & 0 & 0,0 & \\
\hline 0,6 & 1 & 3,7 & 55,6 & 0 & 0 & & 1 & 5,3 & 63,2 & 1 & 6,7 & 53,3 \\
\hline $\begin{array}{l}\text { Total number } \\
\text { of companies }\end{array}$ & 27 & 100,0 & 100 & 24 & 100 & 100 & 19 & 100 & 100 & 15 & 100 & 100 \\
\hline $\begin{array}{l}\text { Average } \\
\text { sample } \\
\text { realization } \\
\end{array}$ & 0,17 & & & 0,12 & & & 0,11 & & & 0,18 & & \\
\hline $\begin{array}{l}\text { Average } \\
\text { performance }\end{array}$ & 0,06 & & & 0,1 & & & 0,06 & & & 0,08 & & \\
\hline
\end{tabular}

Source: Authors' calculations

Thus, the further subject of research focuses on the analysis of interdependence and the impact of the most typical traditional liquidity indicators on one of the most important profitability indicators - ROA. The independent variables taken into analysis for the period from 2016 to 2019 are: Liquidity 1- General liquidity ratio; Liquidity 2- Cash liquidity ratio and Solvency - Relationship between long-term sources and fixed assets. The dependent variable is Profitability - Return on Assets (ROA). In order to fulfill the necessary preconditions for checking the validity of the assumptions, we performed the following checks. Initial correlations between variables in the model are given in the Correlations table (Table 3). Variables with a linear correlation of 0.7 or more should not be included in the same analysis (Pallant, 2010). All three independent variables (LIK1, LIK2, SOL) satisfactorily correlate with the dependent variable (Table 3).

Table 3. Correlation analysis

\begin{tabular}{|c|c|c|c|c|c|}
\hline \multicolumn{6}{|c|}{ Correlations } \\
\hline & & ROA & LIK1 & LIK2 & SOL \\
\hline \multirow{4}{*}{ Pearson Correlation } & $\mathrm{ROA}$ & 1,000 &, 044 & ,003 & ,336 \\
\hline & LIK1 &, 044 & 1,000 &, 626 & ,488 \\
\hline & LIK2 &, 003 & ,626 & 1,000 &, 182 \\
\hline & SOL & ,336 & ,488 &, 182 & 1,000 \\
\hline \multirow{4}{*}{ Sig. (1-tailed) } & ROA & & ,345 & ,488 & ,001 \\
\hline & LIK1 &, 345 & . &, 000 &, 000 \\
\hline & LIK2 & ,488 &, 000 & &, 047 \\
\hline & SOL & 001 &, 000 & ,047 & . \\
\hline
\end{tabular}




\begin{tabular}{|l|l|r|r|r|r|}
\hline \multicolumn{9}{|c|}{ Correlations } \\
\hline \multirow{4}{*}{} & \multicolumn{1}{|c|}{ ROA } & \multicolumn{1}{c|}{ LIK1 } & \multicolumn{1}{c|}{ LIK2 } & \multicolumn{1}{c|}{ SOL } \\
\hline \multirow{3}{*}{$\mathrm{N}$} & ROA & 86 & 86 & 86 & 86 \\
\cline { 2 - 7 } & LIK1 & 86 & 86 & 86 & 86 \\
\cline { 2 - 7 } & LIK2 & 86 & 86 & 86 & 86 \\
\cline { 2 - 7 } & SOL & 86 & 86 & 86 & 86 \\
\hline
\end{tabular}

Source: Authors' calculations

In the Table 4 we can see that the Tolerance for each independent variable is less than 0.10 , so the assumption of the absence of multicollinearity is not violated. This conclusion is also supported by the VIF values that are below the intersection point 10 .

Table 4. Collinearity test

\begin{tabular}{|r|rr|}
\hline \multicolumn{3}{|c|}{ Collinearity Statistics } \\
\hline Tolerance & & \multicolumn{1}{|c|}{ VIF } \\
\hline, 463 & & 2,160 \\
\hline, 587 & 1,702 \\
\hline, 737 & & 1,357 \\
\hline
\end{tabular}

Source: Authors' calculations

On the Figure 1. of normal probability (Normal P-P Plot) we can see that the points lie in an approximately straight diagonal line from the lower left to the upper right corner of the diagram, which indicates that there are no large deviations from normal.

Figure 1. Figure of normal probability

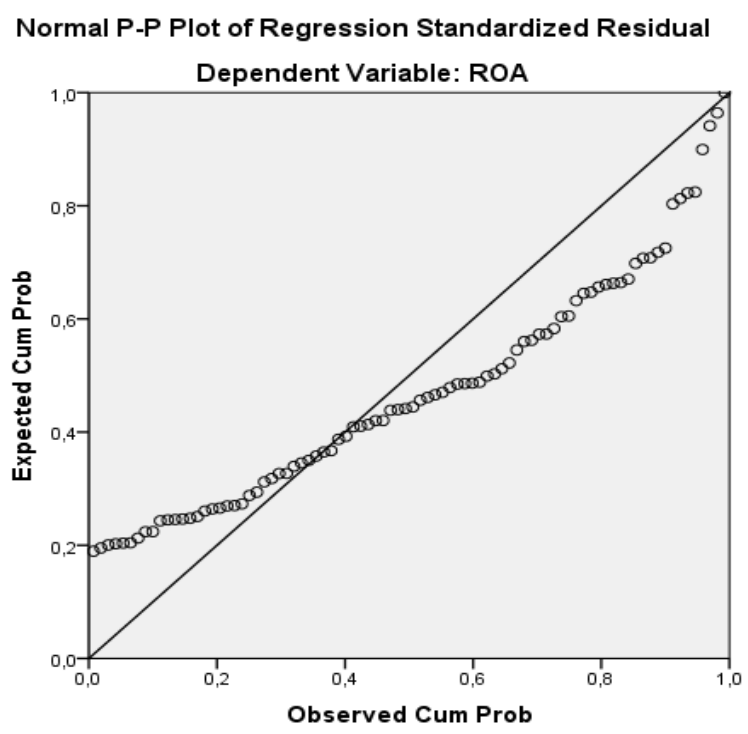

Source: Authors' calculations 
In the Figure 2 of scatterplot of standardized residues, the residues are approximately rectangularly distributed and most of the scatter points are accumulated in the center (around point 0 ).

Figure 2. Scattering diagram

Scatterplot

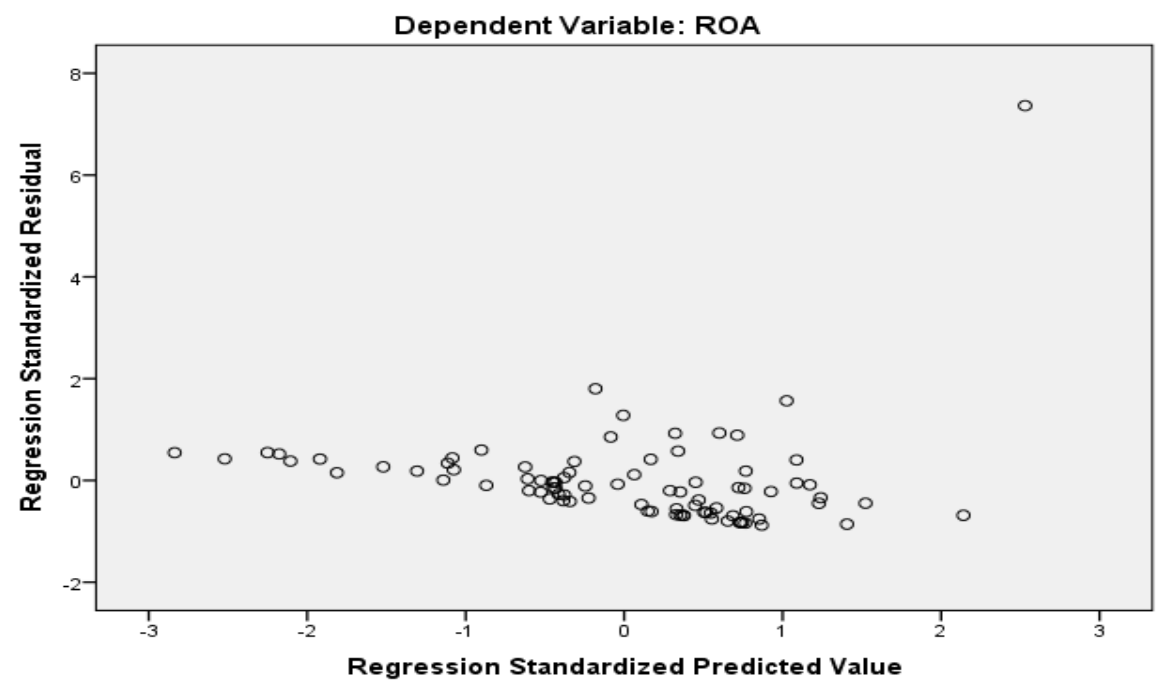

Source: Authors' calculations

In the Table 5, "R" represents the value of the multiple correlation coefficient used to determine the prediction quality of the dependent variable, in this case ROA. A value of 0.36 represents a good level of prediction. The column " $\mathrm{R}$ Square" represents the decision coefficient, i.e. the dispersion ratio of the dependent variable that can be explained by independent variables. The value of 0.133 represents $13.3 \%$ of the variability of the dependent variable which can be explained by the independent variables.

Table 5. Model evaluation

\begin{tabular}{|l|r|r|r|r|}
\hline \multicolumn{5}{|c|}{ Model Summary $^{\mathbf{b}}$} \\
\hline Model & R & R Square & Adjusted R Square & Std. Error of the Estimate \\
\hline 1 &, $365^{\text {a }}$ &, 133 &, 101 &, 08781 \\
\hline \multicolumn{4}{|l}{ a. Predictors: (Constant), SOL, LIK2, LIK1 } \\
\hline
\end{tabular}

Source: Authors' calculations

F-value in the Table 6, shown below, tests whether the regression model is good. The table shows that the independent variables statistically predict the dependent variable well $($ Sig. $=.008)$ and this actually means that our regression model is good $\mathrm{F}(3.82)=$ $4.193, \mathrm{p}<0.05$. 
Table 6. Regression model test

\begin{tabular}{|l|l|r|r|r|r|r|}
\hline \multicolumn{7}{|l|}{ ANOVA $^{\text {a }}$} \\
\hline \multicolumn{2}{|l|}{ Model } & \multicolumn{1}{c|}{$\begin{array}{c}\text { Sum of } \\
\text { Squares }\end{array}$} & df & Mean Square & F & Sig. \\
\hline \multirow{3}{*}{1} & Regression &, 097 & 3 &, 032 & 4,193 &, $008^{\text {b }}$ \\
\cline { 2 - 8 } & Residual &, 632 & 82 &, 008 & & \\
\cline { 2 - 7 } & Total &, 729 & 85 & & & \\
\hline \multicolumn{2}{|l}{ a. Dependent Variable: ROA } \\
\hline \multicolumn{2}{|l}{ b. Predictors: (Constant), SOL, LIK2, LIK1 }
\end{tabular}

Source: Authors' calculations

From the Table 7 we arrive at the regression equation which reads $\mathrm{ROA}=0.042-$ $(0.019 \times$ LIK 1$)+(0.012 \times$ LIK 2$)+(0.053 \times$ SOL $)$. We then proceed to determine the significance of independent variables $\mathrm{p}<0.05$ and conclude that only one independent variable makes a statistically significant contribution to our research and that is the Ratio of long-term sources and fixed assets (SOL). Neither the variable Current Liquidity Ratio (general liquidity ratio - LIK1) nor the Current Liquidity Ratio (cash liquidity ratio - LIK2) for the period 2016-2019 have provided statistically significant predictions of the variable return on assets (ROA).

Table 7. Estimates of model coefficients

\begin{tabular}{|c|c|c|c|c|c|c|c|c|}
\hline \multirow{2}{*}{\multicolumn{2}{|c|}{ Model }} & \multicolumn{2}{|c|}{$\begin{array}{l}\text { Unstandardized } \\
\text { Coefficients }\end{array}$} & \multirow{2}{*}{$\begin{array}{c}\begin{array}{c}\text { Standardized } \\
\text { Coefficients }\end{array} \\
\text { Beta }\end{array}$} & \multirow{2}{*}{$\mathbf{t}$} & \multirow{2}{*}{ Sig. } & \multicolumn{2}{|c|}{$\begin{array}{l}95,0 \% \text { Confidence } \\
\text { Interval for B }\end{array}$} \\
\hline & & B & $\begin{array}{c}\text { Std. } \\
\text { Error }\end{array}$ & & & & $\begin{array}{l}\text { Lower } \\
\text { Bound }\end{array}$ & $\begin{array}{l}\text { Upper } \\
\text { Bound }\end{array}$ \\
\hline \multirow{4}{*}{1} & (Constant) &, 042 &, 020 & & 2,100 & ,039 &, 002 & ,081 \\
\hline & LIK1 &,- 019 &, 015 &,- 190 & $-1,257$ & ,212 &,- 050 & ,011 \\
\hline & LIK2 &, 012 &, 035 &, 046 &, 342 &, 733 &,- 058 &, 083 \\
\hline & SOL &, 053 & ,015 & , 420 & 3,508 & ,001 & ,023 &, 083 \\
\hline
\end{tabular}

Source: Authors' calculations

We can conclude that multiple regression was performed to determine the best linear combination of LIK1, LIK 2 and SOL for ROA prediction. From the Table 7 we see that this combination of variables significantly predicted $13.3 \%$ of the variability of the dependent variable $(\mathrm{R} 2=.13, \mathrm{~F}(3.82)=4.19, \mathrm{p}<.01)$. In our study, we found that only one variable "The ratio of long-term sources to fixed assets" $(\beta=.53, p<.001)$, in our model, makes a statistically significant contribution to the prediction of the return on assets. If the solvency, i.e. the ratio of long-term sources and fixed assets increases by one unit, the ROA coefficient shall increase by 0.053 . 


\section{Conclusions}

The profit position of a company is influenced by numerous factors and in this paper the authors wanted to additionally explore the impact of liquidity in the meat processing activity in the Republic of Serbia in the period 2006-2019. Previous research has shown the connection of these categories in different economic activities. The analysis of meat processing activity in the Republic of Serbia, in the period 2006-2019, gives a markedly unfavorable assessment of the liquidity position, and a somewhat more favorable assessment of the profit position. The findings of the regression analysis show a statistically significant and positive impact of the selected solvency ratio on the return on assets - ROA, while the impact of general and cash liquidity ratio is not statistically significant. The obtained results justify the process of analysis of "liquidity-profitability trade off' in order to show how a platform for rational management of liquidity and profitability of the company could be created. The further course of research on the issue of "liquidity profitability trade off" on the one hand should be focused on other activities and types of companies, and on the other hand on a wider range of liquidity and profitability indicators.

\section{Conflict of interests}

The authors declare no conflict of interest.

\section{References}

1. Agencija za privredne registre (APR). Retrieved from http://www.apr.gov.rs (23.06.2021.).

2. Afza, T., \&Nazir, M. (2007). Working Capital Management Policies of Firms: Empirical Evidence from Pakistan, Conference Proceedings of 9th South Asian Management Forum (SAMF), North South University, Dhaka, Bangladesh 24-25 February.

3. Ahmad, R. (2016). A Study of Relationship between Liquidity and Profitability of Standard Chartered Bank Pakistan: Analysis of Financial Statement Approach. Global Journal of Management and Business Research: C Finance, 16 (1), 76-82.

4. Bagchi, B., Chakrabarti, J., \& Basy Roy, P. (2012). Influence of Working Capital Management on Profitability: A Study on Indian FMCG Companies, International Journal of Business and Management, 7(22), 1-10.

5. Mohamed, B.N., \& Saad, B. M. (2010): Working Capital Management: The effect of Market Valuation and Profitability in Malaysia. International Journal of Business and Management, 5(11), 140-147. doi: 10.5539/ijbm.v5n11p140.

6. Čavlin, M. (2015). Strateška analiza perfomansi preduzeća iz trgovine farmaceutskim proizvodima u Republici Srbiji primenom integrisanog sistema pokazatelja. Megatrend revija, 12(1), 237-256. doi: 10.5937/MegRev1501237C. 
7. Čavlin, M., \& Tepavac, R. (2020). Mogućnost primene klasičnih bilansnih modela za prognozi solventnosti - primer MSP u ruralnim područjima Republike Srbije. U : Turizam i ruralni razvoj (str. 506-523). Univerzitet Kragujevac, Vrnjačka Banja.

8. Deloof, M. (2003). Does Working Capital Management Affect Profitability of Belgian Firms?. Journal of Business Finance and Accounting, 30 (3/4), 573-587.

9. Dencic-MIihajlov, K. (2015). Profitability during the financial crisis: evidence from the regulated capital market in Serbia. South-Eastern Europe Journal of Economics, 12(1), 7-33.

10. Ehi-Oshio O. U., Adeyemi A., \& Enofe, O. A. (2013): Determinats of corporate profitability in developing economies. European Journal of Business and Management, 5 (16), 42-5.

11. Ehiedu, V. (2014). The Impact of Liquidity on Profitability of Some Selected Companies: The Financial Statement Analysis (FSA) Approach Research. Journal of Finance and Accounting, 5 (5), 81-90.

12. Eljelly, A. (2004). Liquidity - profitability tradeoff: an empirical investigation in an emerging market. International Journal of Commerce and Management, 14 (2), 48-61.

13. Garcia-Teruel., J., \& Martinez-Solano, P. (2007). Effects of working capital management on SME profitability. International Journal of Managerial Finance, 3(2), 164-177.

14. Gill, A, Nahum, B, \& Neil, M. (2010). The Relationship between Working Capital Management and Profitability: Evidence From The United States. Bus. Econ. J., 1-9.

15. Irawan, A., \& Faturohman, T. (2015). A Study of Liquidity and Profitability Relationship: Evidence from Indonesian Capital Market. Proceedings of 31st The IIER International Conference, Bangkok, Thailand, 2nd Aug. 2015, ISBN: 97893-85465-65-9.

16. Jokić, M. (2020). The importance of considering internal audit as a decision-making by top-management of an agricultural company. Oditor - časopis za menadžment, finansije i pravo, 6(3), 123-136. https://doi.org/10.5937/Oditor2003123J

17. Jovanović, D., Todorović, M. \& Grbić, M. (2017). Financial Indicators as Predictors of Illiquidity. Romanian Journal for Economic Forecasting, 20(1), 128-149.

18. Khidmat, W., \& Rehman, M. (2014). Impact of Liquidity and Solvency on Profitability Chemical Sector of Pakistan. EMI Journal, 6 (3), 3-13.

19. Kung'u, J. (2017). Effect of Liquidity Management Practices on Profitability of Manufacturing Industry in Kenya. IOSR Journal of Economics and Finance, 8 (1), 84-89. 
20. Lamberg, S. \& Vålming, S. (2009). Impact of Liquidity Management on Profitability a study of the adaptation of liquidity strategies in a financial crisis. Masters Dissertation. Umeå School of Business. University of Umea, Umea.

21. Levin, R., \& Travis, V. (1987). Small Company Finance: What the Books Don't Say. Harvard Business Review, 65 (6), 30-32.

22. Lukic, R. (2012). Sustainable development of retail in Serbia. Revista de Management Comparat International, 13(4), 574-586.

23. Maçãs Nunes, P. Serrasqueiro, Z, \& Leitão, J.(2010). Are there nonlinear relationships between the profitability of Portuguese service SME and its specific determinants?. The Service Industries Journal, 30 (8), 1313-1341.

24. Mamić Sačer, I., Tušek, B., \& Korica, I. (2013). Empirijska analiza utjecaja likvidnosti na profitabilnost hrvatskih srednjih i velikih poduzeća u grani djelatnosti informacije i komunikacije. Zbornik Ekonomskog fakulteta u Zagrebu, $11(2), 15-35$.

25. Makori, D., M., \& Jagongo, A. (2013). Working capital management and firm profitability: Empirical evidence from manufacturing and construction firms listed on Nairobi securities exchange, Kenya. International Journal of Accounting and Taxation, 1(1), 1-14.

26. Milojević, I., Mihajlović, M., \& Pantić, N. (2020). Collection and documentation of audit evidence. Oditor - časopis za menadžment, finansije i pravo, 6(2), 77-90. . https://doi.org/10.5937/Oditor2002077M

27. Mohamed K., \& Hazem S. (2015). Determinants of Profitability: Evidence from Industrial Companies Listed on Muscat Securities Market. Review of European Studies, 7 (11), 303.-311.

28. Pallant, J. (2010). SPSS Survival Manual: a Step by Step Guide to Data Analysis Using SPSS. Open University Press/McGraw-Hill, Maidenhead.

29. Priya, K., \& Nimalathasan, B. (2013). Liquidity Management and Profitability: A Case Study of Listed Manufacturing Companies in Sri Lanka. International Journal of Technological Exploration and Learning, 2 (4), 161-165.

30. Radić, N., Radić, V., \& Stevanović, M. (2020). Economic impact of the coronavirus pandemic on the automobile industry. Oditor - časopis za menadžment, finansije i pravo, 6(3), 55-88. https://doi.org/10.5937/Oditor2003055R

31. Radović-Marković, M., \& Hanić, H. (2018). Metodologija istraživanja u ekonomskim naukama. Beogradska bankarska akademija, Fakultet za bankarstvo, osiguranje i finansije, Institut ekonomskih nauka, Beograd. ISBN 978-86-7852038-9

32. Raykov, E. (2017). The liquidity-profitability trade-off in Bulgaria un terms of the changed financial managament function during crisis. Journal of Contremporary Managament Issues, 22(1), 135-156. 
33. Rosner, B. (2011). Fundamentals of Biostatistics, 7th Edition. Brooks/Cole, Boston.

34. Saleem, Q., \& Rehman R. (2011). Impacts of liquidity ratios on profitability. Interdisciplinary Journal of Research in Business , 1 (7), 95-98.

35. Saluja, P. P., \& Kumar, P. P. (2012). Liquidity and Profitability Trade-off. International Journal of Advanced Research in Management and Social Sciences, 1 (3), 77-84.

36. Samiloglu, F., \& Dermirgunes, K. (2008). The Effect of Working Capital Management on Firms' profitability: Evidence from Turkey. The International Journal of Applied Economics and Finance, 2 (1), 44-50.

37. Smith, K, (1980). Profitability versus liquidity tradeoffs in working capital management, Readings on the management of working capital. West Publishing Company, New York, St. Paul.

38. Stevanović, S.,Minović,J.,\& Marinković,G. (2021). Earnings and cash flow peristence - Case of medium agriculture enterprises in Serbia. Ekonomika poljoprivrede, 68 (1), 141-153. doi:10.5937/ekoPolj2101141S

39. Stevanović, S. Minović,J.,.\& Ljumović, I. (2019). Liquidity Profitability Tradeoff: Evidence from Medium Enterprises. Management: Journal of Sustainable Business and Management Solutions in Emerging Economies, 24 (3), 71-80. ISSN 1820-0222

40. Uyar, A. (2009). The Relationship of Cash Conversion Cycle with Firm Size and Profitability: An Empirical investigation in Turkey. International Research Journal of Finance and Economics, 24, 186-193. 